\title{
Obstacles and strategies for the sustainability of Indonesian small and medium enterprises during Covid-19 Pandemic: A study case at Reban Lestari Farm Kolaka Sulawesi Tenggara
}

\author{
Hastuti ${ }^{*}, 1$, Hasnidar ${ }^{2}$, Bustang ${ }^{3}$ \\ ${ }^{1}$ Department of Animal Husbandry, Faculty of Agriculture, Fisheries and Animal Husbandry, Universitas \\ Sembilanbelas November Kolaka, Sulawesi Tenggara, Indonesia, 93517 \\ ${ }^{2}$ Department of Accounting, Faculty of Social and Political Sciences, Universitas Sembilanbelas November \\ Kolaka, Sulawesi Tenggara, Indonesia, 93517 \\ ${ }^{3}$ Department of Accounting, Faculty of Social and Political Sciences, Universitas Sembilanbelas November \\ Kolaka, Sulawesi Tenggara, Indonesia, 93517 \\ *Correspondence: hastutijalla@gmail.com
}

Received: June 19th 2021 ; Accepted: November 10th, 2021 ; Published online: November $17^{\text {th }}, 2021$

\begin{abstract}
Abstrak
Tujuan: Tujuan penelitian ini adalah untuk mengkaji keberlanjutan UMKM setelah terkena dampak pandemi Covid-19. Objek penelitian ini adalah UMKM Peternakan Ayam Petelur, Reban Lestari Farm Kabupaten Kolaka.

Metode: Pendekatan penelitian menggunakan pendekatan kualitatif dan interpretif. Teknik pengumpulan data dilakukan melalui wawancara dan observasi. Teknik analisis data dilakukan dengan analisis deskriptif kualitatif.

Hasil: Hasil penelitian ini menunjukkan bahwa adanya pandemic Covid-19, memberikan dampak terhadap usaha mikro, kecil dan menengah, tetapi terdapat usaha yang mampu tetap bertahan dan tumbuh meskipun adanya pandemic. Usaha mikro dan kecil seperti peternakan ayam petelur merupakan salah satu usaha yang secara konsisten dapat bertumbuh karena adanya kebutuhan masyarakat yang cukup tinggi saat pandemic terjadi.

Kesimpulan: Keberlanjutan UMKM masih dapat dipertahankan dengan berbagai bentuk strategi bisnis yang baik, melakukan inovasi dan berpikir kreatif untuk bisa meningkatkan kualitas produk dan penjualan.
\end{abstract}

Kata Kunci: business sustainability; Covid-19 pandemic; hambatan; strategi bisnis; MSMEs

Abstract

Objective: This study aimed to assess the sustainability of Indonesian Micro, Small, and Medium Enterprises (MSME) during the Covid-19 pandemic. The specific object of this study was Reban Lestari Farm, an MSME of laying hens farm located in Kolaka, Southeast Sulawesi, Indonesia.

Methods: The study composed a qualitative and interpretive approach. Data were collected through interviews and observations, and data were analyzed by using a qualitative descriptive analysis.

Results: Results show that the Covid-19 pandemic had significant effects on Indonesian MSMEs, but some MSMEs can survive and even grow despite the pandemic. Laying hens farm was one of the 
MSMEs that can survive and consistently grow during the Covid-19 pandemic as the commodity still has a high demand amongst consumers.

Conclusions: The sustainability of an MSME can still be maintained with multiple business strategies, such as developing innovation and creative thinking to improve product quality and income.

Keywords: business strategies; business sustainability; Covid-19 pandemic; MSME (micro, small, and medium enterprises); obstacles

\section{INTRODUCTION}

Micro, Small, and Medium Enterprises (MSME), or in Indonesian is called Usaha Mikro, Kecil dan Menengah (UMKM), is one of the sectors that move as the foundation of a national economy that contributes to a sustainable national awakening [1]. MSMEs contribute to the national economy through equal distribution of people's economy, whereas all people have the same opportunity to develop MSMEs. MSMEs also absorb labor. MSMEs can contribute to alleviating poverty in Indonesia. With a rise in the number of MSMEs, transaction and trade value both nationally and internationally are also increased. MSMEs also contribute to enhancing the country's foreign exchange [2]. Based on Law Number 20 of 2008 concerning Micro, Small, and Medium Enterprises in article 3, the Micro, Small, and Medium Enterprises state that MSMEs players aim to improve and advance their business in the national economic development plan based on a just economy.

In ASEAN, MSMEs generate employment between $50 \%$ and $95 \%$ and contribute between $30 \%$ to $50 \%$ of GDP [3]. In Indonesia, MSMEs are one of the strategic sectors in the national economy [4].

The agricultural sub-sector includes agriculture, plantations, and animal husbandry. The livestock sub-sector is one of the sub-sectors that contributes to the national economy and could absorb labor significantly. It can be relied upon in efforts to improve the national economy [5]. It can be said that the livestock sub-sector has a role in business development that significantly contributes to the development and has strategic value, especially for efforts to meet domestic animal protein needs, and has a role in taking advantage of job opportunities. One of the businesses in the livestock sub-sector is laying hens.

Since the COVID-19 outbreak in March 2020, BPS made an initial prognosis regarding the supply and demand of livestock products during 2020. According to BPS data (2020) that supply and demand for eggs in the last five years were quite volatile but still showed a positive trend. In 2017, egg production had decreased by 4.30 percent compared to the previous year but again showed an increasing trend to reach 1,984 thousand tons in 2020. Meanwhile, egg consumption grew positively from year to year during the 2014-2020 period. The following is a special Supply-Demand graph for Chicken Eggs in 2020 (tons) carried out by the Central Statistics Agency, specifically in 2020 during a pandemic (Figure 1).

Figure 1 shows the fluctuation of supply and demand for broiler eggs in 2020 during the pandemic. May is the month that experienced an increase in both supply and demand for broiler eggs. This condition is because, during the COVID-19 pandemic, the enactment of regional restrictions resulted in public demand and the government balancing the supply of flavored chicken eggs in the community.

The impact of the Covid-19 pandemic on MSMEs can be viewed from the side of supply and demand [6]. According to [4], from the supply side, Covid-19 makes many MSMEs experiencing labor shortages due to existing social restrictions and maintaining workers' health. From the side of demand, reduced demand for goods or services resulted in MSMEs not functioning optimally, which resulted in a lack of business liquidity. In the end, many people will lose income as MSMEs cannot pay workers' wages or even lose their job due to unilateral termination of employment. 


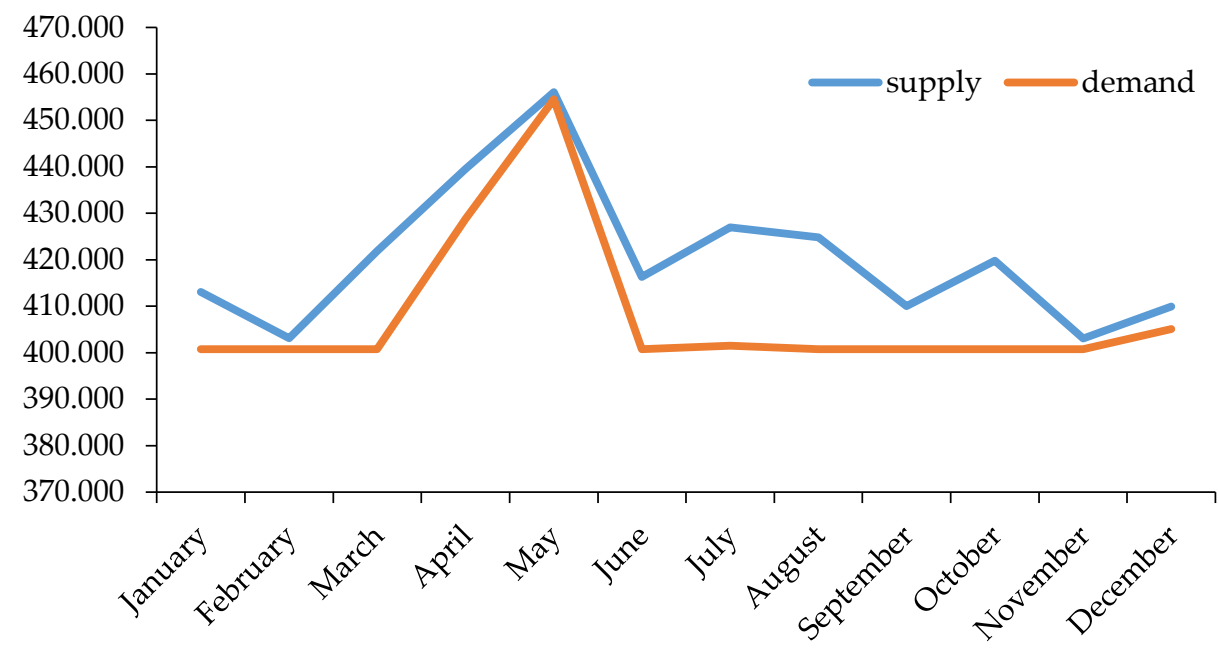

Figure 1. Supply-Demand of Chicken eggs in 2020 (Ton)

Business sustainability seen from business growth is the ability of the organization to increase the size of an organization or company [7]. Business growth can be measured in absolute or relative terms from changes in sales, assets, employment, business productivity, profits. In each stage of development, different factors are very important for the sustainability of business growth and the success of MSMEs [8]. According to [9], collaborative modes of operation, government policies, and facilitation, supporting organizational culture can positively affect SMEs' sustainability performance and improve their financial performance. Furthermore, according to [10], various factors and organizational dynamics contribute to the initiation of sustainability reporting and the progressive spread of sustainability practices within organizations in small and medium enterprises (SMEs). Thus, it could be said that there are several mutually supportive aspects to achieve business sustainability both in terms of internal and external business, namely a regulation, government facilities, to business management capabilities, namely finance and organizational culture.

One Indonesian MSMEs affected by the Covid-19 pandemic were laying hens farming businesses in Kolaka Regency, Southeast Sulawesi Province, Indonesia. Many farmers complained that the Covid-19 pandemic affected their business growth and financial condition due to increased prices for animal feed, increased costs for livestock medicines and vitamins, and fluctuations in egg prices in the market. Such a situation made their profits decline, and their business development was hampered. However, other conditions may also affect their business finances, such as managing the business, which harms its financial situation properly. This study aimed to describe the sustainability of the MSME in facing the Covid-19 pandemic. Besides, this study also aimed to provide an overview of the MSME players' strategies.

This study aims to describe the sustainability of MSMEs in dealing with the impact of the Covid-19 pandemic on Reban Lestari Farm. In addition, the research was intended to provide an overview of the strategies. It can be carried out by MSME actors, especially in the livestock business sector. Currently, the growth of business actors in MSME commodities is increasing every year, especially in Kolaka Regency, Southeast Sulawesi. Thus, the implications of this research are to assist business actors in starting and maintaining situations that cannot be avoided. Through this research, policymakers, especially local governments, can consider policies that can help local MSME actors so that they can advance the region by understanding the situation and elaborating the policy to be made.

\section{MATERIALS AND METHODS}

This study employed a qualitative approach with descriptive qualitative analysis methods. According to [11], descriptive 
research aims to identify, understand, and describe the characteristics of humans, events, or situations as the center of the research. In addition, a qualitative approach was selected as it can help to think systematically on a specific occasion and provide ideas for further investigation while simplifying the decision-making process.

The procedure of this study through three processes that refer to [12], namely:

1. Make a plan; in this process, identify the problems that occur by making initial observations on the object of research and then formulating research questions.

2. Collect data; in this process, the researcher collects data as needed in the study. The collection process involves further observations, interviews, documentation, and triangulation or a combination.

3. Analyze and describe the data; in this process, the data that has been obtained is then analyzed. Then make a statement of the results to the conclusion.

According to [13], triangulation is a data collection technique that combines various data collection techniques and existing data sources. in this study; triangulation combines observation, interviews, and documentation and data collection through filling out questionnaires made previously. The questionnaire is intended to maintain the consistency of the observations and statements from the interviews conducted. The research instrument is a questionnaire containing statements, and a score column that can be given to the statements submitted include (1) the subject gets knowledge about entrepreneurship and the opportunity to become an entrepreneur; (2) the subject fully believes that running a laying hens business must have a good knowledge base; (3) the subject believes that the laying hen's commodity business provides great opportunities in business; (4) the subject believes that the laying hens business is not affected by the covid-19 pandemic; (5) the subject believes that good relations with customers are important in maintaining business; (6) the subject believes that government policies support the business being carried out; (7) the subject will continue the business he is running until he succeeds in becoming an entrepreneur.

The parameter measured in this research is the sustainability of micro, small and medium enterprises related to the dimensions of barriers and strategies to support business sustainability. Meanwhile, the subject of this research is Laying Chicken Farm in Kolaka Regency, Indonesia, namely Reban Lestari Farm. Reban Lestari Fram meets the criteria as a research subject, which inclusion criteria in this study are (1) MSME businesses experiencing the impact of COVID19 on the livestock business sector and (2) having a Business Identification Number (NIB). This research was also carried out in February 2020.

The data was obtained in secondary data, interviews, field observations, and questionnaires given to the subject. The process of collecting data was for two weeks by applying the health protocol when conducting field observations. In addition, the researchers also took three subjects as a source of support which became the work relations of the research subjects, including customers as MSMEs who were interrelated with Reban Lestari Farm as a supplier of laying hens. It is done because the business continuity perception of coworkers will provide supporting statements in researchers compiling research reports.

Data analysis in this study used descriptive qualitative method analysis to provide a description and get a clear picture to answer the problem formulation in the research interactively and continuously until it was completed so that the data was saturated [13]. Activities in data analysis, namely (1) data reduction related to data obtained from the field, are quite a lot, for that, it needs to be recorded carefully and in detail; (2) display data related to data presented in the form of tables, graphs, and the like so that the data is arranged in a relationship pattern and is easy to understand, and (3) conclusion drawing/verification related to concluding the formulation of problems that have been made previously regarding the impact of the COVID-19 pandemic on the sustainability of MSMEs and what strategies are used to survive amid the COVID-19 pandemic. 


\section{RESULTS}

According to the interviews and observations of the owner, Reban Lestari Farm started its business in November 2019, just before Covid-19 Indonesia's first case was identified in March 2020. The owner said it took approximately one year to prepare the business for operation, such as providing capital, administering the NIB, setting the farm, establishing the henhouse, and importing the chickens from another region.

Law Number 11 of 2020 concerning Job Creation or Omnibus Law had benefitted the MSMEs such as Reban Lestari Farm to get a business license (NIB). However, despite all this, the law provides benefits for MSMEs players in Indonesia. MSMEs can absorb more workers, and there is open access to finance, market, and business development. Previously, MSMEs actors needed to have assets as collateral to access financing, but currently, their business activities can be considered assets for MSMEs to get funding. The regulation supports the MSME through the easiness of starting a business. As a result, Reban Lestari Farm obtained a micro and small business license on February 23, 2021, with the business type of Layer Poultry Farming.

Reban Lestari Farm is grouped in the Micro Enterprises scale. This scale allows the business to have capital up to IDR 1 billion, while Reban Lestari Farm had the venture capital of IDR 120 million. This value accounted for cage equipment and other current assets, excluding land and buildings, with an estimated depreciation cost of IDR 25 million per year.

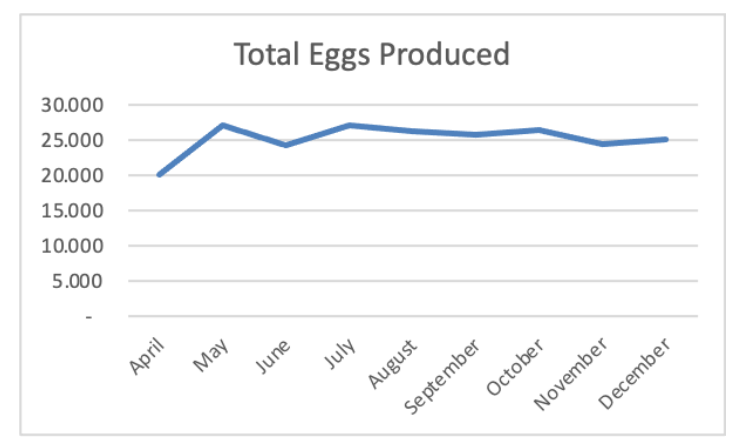

Figure 2. Eggs produced at Reban Lestari Farm in 2020 .
According to Article 31 of Government Regulation Number 24 of 2018 concerning Electronically Integrated Business Licensing Services, the business licensing process was completed online. To the Reban Lestari Farm owner experience, it took two months to obtain the license. Overall, the owner needed only one year to finish the administrative process. Owning the business license enables the business owner to access financial banking services and involve in government stimulating programs in MSMEs development.

Figure 2 describes the MSME's egg production and gross income per month by selling IDR 41,000 - IDR 50,000 of one egg rack containing 30 eggs. The first egg-harvesting season of Reban Lestari Farm was in April 2020, and it took about 3-4 months for laying hens before producing eggs.

The first egg production in April 2020 was 20,175 eggs, and the highest production during 2020 was 27,160 eggs in July (Figure 2). Both graphs' revenue and egg production patterns were similar, with the highest income earned being IDR 40,740,000 in July 2020 (Figure 2 and 3 ).

The Urban Lestari Farm had other revenue sources, i.e., compost sales to the community and the fruits planted surrounding the farm, such as papaya, pineapple, and dragon fruit. The values from both selling compost and fruits reached IDR 500,000 to IDR $1,000,000$ in a month.

The farm had spent a monthly cost of IDR $22,650,000$, which the feed cost accounted for the most significant spending with a monthly value of IDR $18,350,000$. Other monthly costs were drugs and vitamins of IDR 1,000,000,

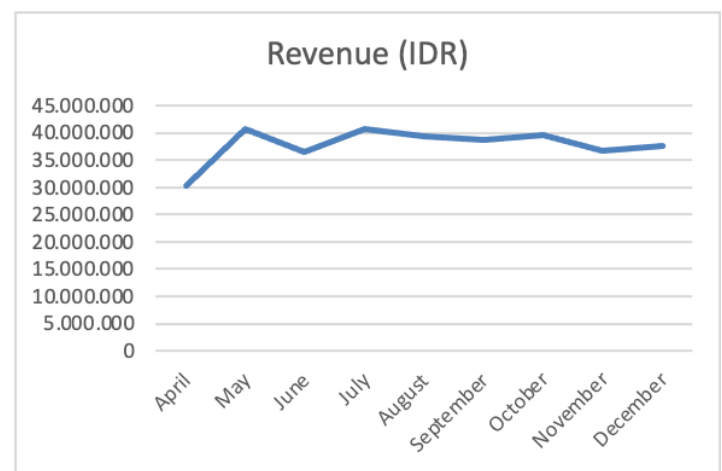

Figure 3. Reban Lestari Farm's gross income in 2020 
cleaning liquid (disinfectant) of IDR 100,000, electricity bill of IDR 200,000, the employee salaries up to IDR 2,500,000 for three workers, and other expenses IDR 500,000.

The interview results identified information about the obstacles faced and the strategies used by the MSME during the Covid-19 pandemic. One of the significant obstacles was the limited distribution to neighboring regencies or provinces due to travel restrictions imposed by the Indonesian government to prevent the spread of the Covid-19 virus. The restriction also delayed the provision of the feed within the Kolaka regency. It was since the feed was transported from outside Kolaka. The delays increased the feed price and were a bit challenging to find in the market. Thus, the farm production costs also increased, but the egg price was still low due to more eggs available at the market but low demand. This condition occurred for quite some time.

For the strategies, the MSME implemented the direct sale of the eggs to other MSME or direct consumers, creating cooperation between them to control the overproduction stock. The farm also kept the production records accurately to ensure the quality of the livestock product. In addition, they also sold the other agricultural products planted around the farm to generate income to maintain the farm's financial condition because one of the supporting businesses to keep running is to have sufficient funds to finance business needs. The strategies implemented can be seen as the farm's ability to deal with opportunities and manage challenges to keep the business running well. The opportunity in question is to keep the business operating and expand (development) the existing business.

Meanwhile, based on the results of the responses to the questionnaire or the questionnaire given, the subject answered a score of 5 in the questionnaire, which means that they strongly agree that (1) the subject has knowledge about entrepreneurship and the opportunity to become an entrepreneur; (2) the subject fully believes that running a laying hens business must have a good knowledge base, the subject gives a score of
4 meaning agree; (3) the subject believes that the laying hens commodity business provides a great opportunity in the business, the subject gives a score of 5 which means strongly agree; (4) the subject believes that the laying hens business has not experienced an impact due to the covid-19 pandemic, the subject gives a score of 2 which means that he does not agree; (5) the subject believes that good relations with customers are important in maintaining business, the subject gives a score of 5 which means strongly agree; (6) the subject believes that government policies support the business being carried out, the subject gives a score of 5 which means strongly agree; (7) the subject will continue the business that is run until it succeeds in becoming an entrepreneur, the subject gives a score of 5 which means strongly agree.

\section{DISCUSSIONS}

Indonesia is one of the countries affected by the pandemic, especially on the economic side [14]. The Covid-19 pandemic forced several Indonesian MSMEs which unable to survive to terminate their business. Through the Job Creation Act benefit for MSMEs, it is expected that the MSMEs will recover quickly during the pandemic situation [15]. The central government created many incentives for MSMEs through the Covid-19 National Economic Recovery (PC-PEN) fund by allocating a budget of IDR 123.46 trillion to aid the MSMEs across the archipelago, and, by the end of October 2020, the funding has been utilized by IDR 90,42 trillion or $73 \%$ of the total budget [15]. However, the Reban Lestari Farm was excluded from PC-PEN funding because its business license was just granted and had not been immediately registered in the PCPEN database as the targeted MSMEs to receive government assistance.

Every MSME actor has a business strategy in running a business because the strategy is expected to answer challenges and seize existing opportunities through increasingly competitive competition in the future with various advantages it had [16]. According to [17], the business strategy could improve business performance, where business strategy is an activity within 
the company that includes cost leadership, marketing differentiation, and innovation differentiation. Cost leadership was related to a lower cost structure than other businesses and is carried out by cost-efficiency. Marketing Differentiation strategy can be done through service to customers and have a better distribution. Innovative Differentiation Strategy is an activity that includes the creative application of new technology and quality design. In addition, according to [18], MSMEs are required to have good knowledge management and absorptive capacity to improve their business performance. The scalable integration of various initiatives such as access and management of financial resources, opportunity exploration, efficient negotiation, digital adoption, and leadership commitment can help SMEs to survive during the pandemic [19]

This study showed that the Reban Lestari Farm was genuinely affected by the Covid-19 pandemic. Some of the pandemic's impacts identified during this study were (1) intra-city and inter-city travel restrictions that barrier the product distribution in Kolaka City and surroundings; (2) the travel restriction also created difficulties for MSMEs in obtaining feed ingredients from other industrial sectors outside the Kolaka region; (3) price fluctuations of the production materials in the market that affect the selling price, while the demand and supply influence the selling price of the product. According to the farm owner, the unstable (over) supply was because the distributors from outside Kolaka brought similar products at low prices. However, the local farmer tried to resolve this issue by strengthening their business with the regular and loyal customers of their livestock products; (4) the fluctuation of the raw material price and unexpected expenditure by the farm owner contributed to increased monthly cost in the farm.

Based on this study results, it can be concluded that Reban Lestari Farm ran the business consistently and survived during the Covid-19 pandemic. However, this business counted as a relatively new business running and operating for the first year. We have identified several factors why the MSME was able to survive during a pandemic period due to several things such as: first, the MSME has the ability and experience in managing a business, as evidenced by field observations in this study. They made a systematic timeline of essential business activities, such as creating a vaccination schedule for the livestock, keeping a record of daily feed amount, cleaning livestock sheds, and making simple financial reports containing assets, liabilities, and capital. Thus, the ability of the knowledge management process was the most important antecedent of the performance (financial and non-financial) of MSMEs [20]. It is also explained by [21] that knowledge management processes can help entrepreneurs identify and develop effective strategies to improve their overall performance. [22] state that apart from the financial side, business sustainability can be supported and mediated by customer satisfaction, business reputation, and organizational commitment.

Second, MSMEs owners could adapt to the changing consumer behavior, then innovate and think creatively to increase sales. According to [23], to reduce the negative impact of the COVID-19 pandemic on the MSME sector, appropriate and fast innovations are needed to create new activities to ensure the sustainability of their business. For instance, the Reban Lestari Farm sold their eggs to other MSMEs such as cake shops and increased promotion. Promotional activities can be carried out by utilizing technology as a form of creativity and innovation by business actors to reach consumers within and outside the region [24]. Some research results reveal that if e-commerce-based MSME actors have different business strategies from MSME actors who do not use e-commerce [25]. In addition, the livestock waste was processed into compost and sell it to the local community as a source of additional income.

Those two strategies are considered adequate for MSMEs to be applied. According to [26], strategy as planning plays an important role in mediating consumeroriented business performance. Determining the model (strategy) in business can significantly assist SMEs in making decisions 
to facilitate strategic changes in the survival (going concern) and development phase by considering the context of the crisis that can be faced. Good business management in a pandemic or emergency is needed by combining the ethos and regular business operations of SMEs [27], [28], and [19]. According to [8], business growth could be represented by a positive change in sales, assets, performance, business productivity, and profit. In addition, the five indicators mentioned above of the business development are fundamental to be monitored. The cooperation with other industries also urges to be established to sustain business growth and the further success of MSMEs, particularly MSME in the livestock business sector. MSMEs players must think of alternatives to keep their business sustainable, such as reducing inventory stock, conducting surveys of more affordable prices with good quality, and reducing the selling price.

\section{CONCLUSIONS}

The present study concluded that Laying Chicken Farm was one type of MSME that could survive and continue to grow amid the COVID-19 pandemic in Indonesia. The ability to develop laying hens can survive because of several strategies. Such as the ability of business actors to manage the business carefully, and livestock production results can be determined with certainties such as relationships and cooperation between MSMEs and government policies that will affect MSMEs. This study is expected to provide fruitful information for policymakers, scholars, and MSMEs actors to understand the problems and strategies of MSMEs business. However, this study's findings are confined to only one MSME sector (livestock and poultry), so further research reaches more MSME business sectors. More samples or study cases shall be developed in the future.

\section{CONFLICT OF INTEREST}

The authors certify no conflict of interest with any financial, personal, or other relationships with other people or organizations related to the material discussed in the manuscript.

\section{ACKNOWLEDGMENTS}

The authors thank the owner and all the workers in the private Rebam farm in Kolaka.

\section{REFERENCES}

1. Anisah, N. dan L. Pujiati. 2018. Kesiapan usaha mikro kecil dan menengah dalam penerapan standar akuntansi keuangan entitas mikro kecil dan menengah untuk menunjang kinerja. Jurnal Riset Akuntansi dan Keuangan Dewantara, 1(1):45-56.

2. Prasetyo, A. dan M. Huda. 2019. Analisis peranan usaha kecil dan menengah terhadap penyerapan tenaga kerja di kabupaten kebumen. Fokus Bisnis: Media Pengkajian Manajemen dan Akuntansi. 18(1):26-35. Doi: 10.32639/fokusbisnis.v18 i1.309

3. Islam, A. 2020. Configuring a Quadruple Helix Innovation Model (QHIM) based blueprint for Malaysian SMEs to survive the crises happening by Covid-19. Emerald Open Res. 2.

4. Sugiri, D. 2020. Menyelamatkan usaha mikro, kecil dan menengah dari dampak pandemi covid-19. Fokus Bisnis: Media Pengkajian Manajemen dan Akuntansi. 19(1):76-86. Doi: 10.32639/fokusbisnis.v19 i1.575

5. Badan Pusat Statistik. Peternakan Dalam Angka Tahun 2020 [Internet]. BPS; 2020 [cited 09 Jan. 2021].

6. OECD. SME Policy Responses: Tackling Coronavirus (Covid-19) Contributing to A Global Effort [Internet]. OECD; 2020 [cited 20 Feb. 2021].

7. Adomako, S., A. Danso, and J. O. Damoah. 2015. The moderating influence of financial literacy on the relationship between access to finance and firm growth in ghana. International Journal of Entrepreneurial Finance. 9:1-19. Doi: 10.1080/13691066.2015.1079952

8. Rahayu, A. Y. dan Musdholifah. 2017. Pengaruh literasi keuangan terhadap kinerja dan keberlanjutan UMKM di kota Surabaya. Jurnal Ilmu Manajemen. 5(3):1-7. 
9. Das, M., K. Rangarajan, and G. Dutta. 2020. Corporate sustainability in SMEs: An Asian Perspective. J. Asia Bus. Stud. 14(1):109-138. Doi: 10.1108/JABS-10-20170176

10. Rossi, A. and M. Luque-Vílchez. 2021. The implementation of sustainability reporting in a small and medium enterprise and the emergence of integrated thinking. Meditari Accountancy Research. 29(4):966-984. Doi: 10.1108/MEDAR-02-2020-0706

11. Sekaran, U. and R. Bougie. 2016. Research methods for business. $7^{\text {th }}$ ed. John Wiley and Sons, United Kingdom.

12. Bachri, B. S. 2010. Meyakinkan validitas data melalui triangulasi pada penelitian kualitatif. Jurnal Teknologi Pendidikan. 10(1):46-62.

13. Sugiyono. 2016. Metode Penelitian Kuantitatif, Kualitatif dan R\&D. PT Alfabet, Bandung.

14. Pakpahan, A. K. 2020. COVID-19 dan implikasi bagi usaha mikro, kecil, dan menengah. Jurnal Ilmiah Hubungan Internasional. Edisi Khusus:59-64. Doi: 10.26593/jihi.v0i0.3870.59-64

15. Putri, C. A. Omnibus Law UU Cipta Kerja Bikin UMKM Cepat Pulih? [Internet]. Cnbc Indonesia: 2020 [cited: 20 pebruari 2021].

16. Abdillah, M. B., R. M. A., Hakim, D. M. Damiri, dan F. Zahra. 2018. Analisis strategi bisnis pada UMKM kerajinan bambu di Kota Bandung. AdBispreneur: Jurnal Pemikiran dan Penelitian Administrasi Bisnis dan Kewirausahaan. 2(3):227-242. Doi: 10.24198/adbispreneur. v2i3.16491

17. Wardoyo, P., E. Rusdianti, dan S. Purwantini. 2015. Pengaruh orientasi kewirausahaan terhadap strategi usaha dan kinerja bisnis UMKM di Desa UjungUjung, Kec. Pabelan, Kab Semarang. Sustainable Competitive Advantage (SCA). 5(1): 1-19.

18. Fitriyani, I., N. Sudiyarti, dan M. N. Fietroh. 2020. Strategi manajemen bisnis pasca pandemi Covid-19. Indonesian Journal of Social Sciences and Humanities. 1(2):87-95.

19. Islam, A., I. Jerin, N. Hafiz, D. T. Nimfa, and S. A. Wahab. 2021. Configuring a blueprint for Malaysian SMEs to survive through the COVID-19 crisis: The reinforcement of quadruple helix innovation model. Journal of Entrepreneurship, Business, and Economics. 9(1):32-81.

20. Oktafia, R. dan A. R. Hidayat. 2018. Penguatan Kapasitas pelaku bisnis mikro melalui penataan pengelolaan keuangan usaha: pandangan Islam. Jurnal Masharif Al Syariah: Jurnal Ekonomi dan Perbankan Syariah. 3(2). Doi: 10.30651/jms.v3i2.2090

21. Ha, S. T., M. C. Lob, and Y. C. Wang. 2016. Relationship between knowledge management and organizational performance: A Test on SMEs in Malaysia. Procedia Soc. Behav. Sci. 224:184-189. Doi: 10.1016/j.sbspro.2016.05.438

22. Cantele, S. and A. Zardini. 2018. Is sustainability a competitive advantage for small businesses? An empirical analysis of possible mediators in the sustainabilityfinancial performance relationship. J. Clean. Prod. 182:166-176. Doi: 10.1016/ j.jclepro.2018.02.016

23. Hadi, S., H. K. Tjahjono, and M. Palupi. 2020. Study of organizational justice in SMEs and positive consequences: Systematic review. Int. J. Adv. Sci. 29(03):4717-4730.

24. Müller and J. Marius. 2018. Business model innovation in small-and medium-sized enterprises strategies for industry 4.0 providers and users. J. Manuf. Technol. Manag. 30(8):1127-1142. Doi: 10.1108/ JMTM-01-2018-0008

25. Helmalia dan Afrinawati. 2018. Pengaruh e-commerce terhadap peningkatan pendapatan usaha mikro kecil dan menengah di Kota Padang. Jurnal Ekonomi dan Bisnis Islam. 3(2). Doi: 10.15548/ jebi.v3i2.182

26. Sumiati, A. Rofiq, and S. Pramono. 2019. The role of strategic planning and flexibility in shaping SMEs market orientation in turbulence business environment. Eur. Res. Stud. 27(1):221-236.

27. Doshmanli, M., Y. Salamzadeh, and A. Salamzadeh. 2018. Development of SMEs in an emerging economy: does corporate social responsibility matter? International Journal of Management and Enterprise 
Development. 17(2):168-191. Doi: 10.1504/ IJMED.2018.090827

28. Naderibeni, N., A. Salamzadeh, and M. Radović-Marković. 2020. Providing an entrepreneurial research framework in an entrepreneurial university. Int. Rev. 1-2:4356. 